\title{
Health Guidelines about Cervical Cancer for Women and its Effects on their Screening Behavior at El-Suez City
}

Assist Prof. Entesar Fatouh Abd ElMoneim; Dr. Mona Mohamed Younes; Dr.

Elsayda Hamdy Nasr, Azza Shapan Mohamed

Assist Prof. of Maternal and Newborn Health Nursing - Faculty of Nursing - Helwan University; Lecturer of Family \& Community Health Nursing - Faculty of NursingPort Said University; Lecturer of Maternity, Obstetric and Gynecological Nursing Faculty of Nursing - Port said University; BSC Nursing, faculty of nursing, Suez

\section{Canal University}

\begin{abstract}
Background: To evaluate effect of health guidelines about cervical cancer for women on their screening behavior. Subject and Methods: It was carried out in the oncology clinics at health insurance hospital at Suez city using a quasi-experimental (pre \& posttest) design, Purposive non-probability sampling technique. The study subjects were consisted of 102 women attending for follow up in the oncology clinics. An interview schedule was designed and utilized to collect the necessary data. A selfadministered questionnaire was used. Results: showed very poor knowledge (2.0\%) before the implementation of the health guidelines program. This statistically improved after the program to reach $\mathbf{9 8 . 0 \%}$.s. Meanwhile the study revealed that 23.5\% accepted the screening for cervical cancer, while the rest had many health seeking barriers. Conclusion: Health guidelines was effective in improving the knowledge and behavior of women regarding cervical cancer screening and vaccination. There was a significant improvement post intervention in all items of knowledge regarding cervical cancer.
\end{abstract}

Key words: Cervical cancer, knowledge, behavior, screening methods, health-seeking barriers. 


\section{INTRODUCTION}

Cancer cervix is a malignant uncontrolled growth of epithelium cells in the transformation zone, which is the area between the endocervix and ectocervix (Jhingran, et al.2014). It is the third most common cancer in women worldwide. An estimated 500,000 new cases of cervical cancer are identified every year worldwide leading to annual mortality of 270, 000 (Farshbaf-Khalili et al., 2015).

Data from Egyptian studies provide widely varying estimates on the prevalence of pre-invasive cervical lesions ranging from $1 \%$ to $8 \%$ with an age range from 20-60 years. Invasive lesions represented $59.6 \%$ of all female genital tract malignancy according to Egyptian National Cancer Institute data (National Cancer Registry, 2002). This condition affects not only the health and lives of the women, but also their children, families and their communities at large (WHO/ICO Information Centre, 2010).

The risk factors for cervical cancer are sexual intercourse at younger ages, having multiple sexual partners, smoking, immune deficiency, multiparty, diet lacking fresh fruits and vegetables, herpes simplex virus (HSV) type-2 infection, exposure to diethylstilbestrol (DES) in utero, history of intraepithelial neoplasia, familial history of cervical cancer, history of genital wart infection and consumption of oral contraceptives for long period (American Cancer Society, 2013).

Effective screening must meet three targets; at least $70 \%$ of the targeted population should be screened at least once in a lifetime; screening assays and diagnostic tests must be sufficiently sensitive; and specificity for the detection of high-grade precursor lesions and effective treatment must be provided (Rahatgaonkar, 2012). The three screening modalities are cytology (Pap smear), visual inspection, and HPV detection. Pap smear is an effective method of detecting, preventing and delaying the progress of cervical cancer, but requires well trained providers, access to equipment and supplies, cytology laboratory, arrangements for communicating results to screened women and a facility for confirming diagnosis and treatment of the precursor lesions and referring advanced cases (Consul et al., 2012).

Maternity Nurses play a crucial role in the development and management of cancer screening program. These include health education, risk assessment, counseling activities, informing clients about the benefits and barriers of screening, and ensure proper follow-up.

Globally, the incidence of cervical cancer varies widely ranging from 3 to 6 per 100.00 women per year. Screening is the cornerstone of women's preventive health for cervical cancer so that, the main cause of increasing incidence of cervical cancer in Egypt is the lack of regular cervical cancer screening. It is crucial to determine the perceived susceptibility to cervical cancer, as well as the benefits of, and barriers to, cervical cancer screening among women. Collectively educating women about cervical cancer and the utility of screening through continuing education and other 
opportunities may not only result in maintaining or improving health and preventing HPV and cervical cancer but may also contribute to improved screening coverage among women in the general population. However, there are few studies on actual cervical cancer screening adherence of nurses. For this reason, it is important to conduct this study to increase women awareness about cervical cancer and improve their screening behavior.

This study will be done to promote cervical cancer screening behavior among women should focus on informing women of their susceptibility to cervical cancer and encouraging a belief that active and regular screening can detect the pre-cancerous stage, hence enabling early treatment and prevention of cancer development. Women should be encouraged to take responsibility for their own health and be active participants in the screening programmer.

\section{AIM OF STUDY:}

The aim of this study is to evaluate effect of health guidelines about cervical cancer for women on their screening behavior through the following:-

- Assess women knowledge and screening behavior regarding cervical cancer pre the health guidelines.

- Determine effect of health guidelines about cervical cancer on women knowledge and their screening behavior

\section{OPERATIONAL DEFINTION}

-Screening behavior: - brief, formal questionnaires to assessed behavior of women and intention to screen were assessed using tests and investigation to early detection of cervical cancer.

-Health guidelines:-This is theory -based education intervention significantly increased knowledge of intention to screen for cervical cancer, to promote awareness and increase screening rates.

\section{SUBJECT AND METHODS:}

A quasi-experimental (pre \& post) design was used to evaluate the effect health guidelines about cervical cancer for women and its effects on their screening behavior at El- Suez city. The subjects of the study were consisted of 102 women attending for follow up in the oncology clinics. An interview schedule was designed and utilized to collect the necessary data. This study was conducted in outpatient oncology clinics of Health Insurance Hospital at El-Suez City because this setting only includes outpatient oncology clinics. This hospital is affiliated to the Ministry of health. It attracts women from all over El-Suez Governorate. It provides low cost heath services for women with oncology problems compared with other private centers and clinics. 


\section{Three Tools were used for data collection:}

\section{Tool I: The Structured Interview Questionnaire (Appendix I):}

This tool designed mainly to collect data related to:

Socio-demographic data such as: women's name, address, age, education, marital status occupation residence.,Obstetric history such as: Gravid a, parity, birth interval, history of gynecological problems and family planning history and Symptoms encountered as; excessive vaginal discharge, itching in the external genitalia, pain during sexual intercourse, bleeding after intercourse or inter-menstrual and low back ache.

\section{TOOL (II): Pre - post -tests sheet (Appendix II):}

This tool designed mainly to collect data related to:

Assessment of the women's level of knowledge about cervical cancer before and after the implementation of health guidelines such as: Symptoms of cervical cancer, risk factors, prevention and treatment modalities methods.

\section{Scoring System:}

Patient assessment sheet for knowledge consists of (3) closed ended questions, it was formed of multiple choice, the answer was evaluated using model key answer prepared by the researcher, the score was (0) score for incorrect answer \& (1) score for incomplete answer (2) score for complete answer, the total score for knowledge were graded as Poor $<60 \%$, Good $>60 \%$ ). And was categorized in to: satisfactory level if the percent score was $60 \%$ and more and unsatisfactory level if less than $60 \%$.

Assessment of the screening behavior towards cervical cancer: A total of 7 questions were asked to assess the behavior of the participants such as : (Do you think you are at risk of ever having cervical cancer? Do you know anybody (relative, friend) who has had cervical cancer before?, Would you allow a health provider perform a vaginal examination on you even though you have no symptom? Have you ever had a Pap smear test done? And how serious is cervical compared to other forms of cancer?, etc.... the answer ranged from yes, no and I don't know, they were assessed positive or negative.

\section{TOOL (III): Instructional Booklet}

\section{It is guidelines intervention (Appendix III):}

This booklet was done by the researcher and submitted to every woman aiming to improving the knowledge of women and their screening behavior toward cervical cancer. The researcher used simple Arabic language, illustrated pictures to be easily understood by women. The handout booklet was prepared for women and included information about cervical cancer to improve their knowledge, which covered the definition, etiology, signs and symptoms, risk factors and diagnosis of cervical cancer, methods of prevention and different screening methods of cervical cancer.

\section{Content Validity:}

The tools were reviewed by jury of 5 expertise in the field of Obstetrics \&Gynecology to test its contents and face validity. Tools reliability was tested by Cranach Alfa test. 
A pilot study, which was carried out on $10 \%$ from the total sample to evaluate the clarity, and applicability of the tools. Data was collected through a period of 6 months from September 2014 to march 2015 and three phases; two months for assessment phase followed by two months for implementation phase and two months for evaluation phase. Each women was individually filling questionnaire; the questionnaire was collected from all the women while they are in free time of clinic, Women's knowledge and their behavior were assessed regarding cervical cancer, risk factors, and screening methods. The average time needed for completion of each individual interview was 15- 20 minutes for 8 weeks ( 2 days/week) duration of four hours from $10 \mathrm{pm}$ to $2 \mathrm{pm}$. According to the pre and post health, guidelines time schedule for theoretical part.

\section{Ethical Consideration:}

An explanation of the aim of the study was given to every eligible woman before asking her to participate in this study, and oral consent was obtained. Each woman was instructed about her rights to refuse to participate, and to withdraw from the study at any time. Strict confidentiality of any obtained information was ensured. Professional help was provided to the participants. The study maneuvers are scientifically approved, and do not entail any harmful effect on subjects.

\section{RESULTS:}

Table (1): presents distribution of the studied women according to their sociodemographic characteristics. As regards age, it was observed that the majority $(88.4 \%)$ of the study subjects had 40 years and more with a mean of $40.5 \pm 9.3$ years. Meanwhile, more than one third of women had secondary level and university education (35.3\% and 39.2\% respectively). They were mostly housewives, married, living in urban areas and had sufficient income (53.9\%, 69.6\%, 86.3\% and59.8\% respectively). Moreover, their mean crowding index was $1.5 \pm 0.6$.

Table (2): Almost half of the studied women had 3-4 gravida (46.1\%) and partially similar proportion $(52.9 \%)$ had 3-4 Para with a mean of 3 \pm 1.9 . Meanwhile, more than one fourth $(26.5 \%)$ of the studied women had previous history of abortion of those, the majority $(66.7 \%)$ did not seek medical advice.

Table (3): reveals the distribution of the studied women according to the family and gynecological history. More than one fourth (26.5\%) of women had family history of cancer cervix, and $51.0 \%$ complained of vaginal discharge which was accompanied by itching and pruritus. Meanwhile, $11.8 \%$ were exposed to STD and HPV (6.9\%).

Figure (1): shows the distribution of the studied women according to their source of information about cervical cancer. The main source of information was family members and friends (56.97\%). The nurse and the doctor constituted $41.1 \%$ of the sources of information. Meanwhile, the internet (1.1\%) and other visual aids (1.1\%) constituted the least percentages of the source of information among the studied sample. 
Table (4): presents the results of women's knowledge about cancer cervix throughout Health Guidelines. As the table shows, statistically significant improvements were revealed at the posttest in all areas of tested knowledge $(\mathrm{p}<0.001)$. It is evident that the vast majority of women acquired the correct knowledge at the posttest about the definition of cancer cervix, its stages and the presence of early curable measures (98.0\%, 96.0\% and $97.0 \%$ respectively). Meanwhile, a sizable proportion gained the correct knowledge about risk factors, signs and symptoms of cancer cervix at the post test in contrast to the pretest $(78.4 \% \& 80.4 \%$ vs. $1.0 \% \& 0.0 \%$ respectively).

Details of women knowledge related to cancer cervix throughout health guidelines are illustrated in table (5). Statistically significant improvements are noticed in almost all areas at both the post $(\mathrm{p}<0.001)$. The percentages of correct knowledge concerning predisposing factors of cancer cervix, measure for its prevention and the timing for successive pap smear were significantly very high at the post-test compared to those at the pre-test $(6.9 \%, 100.0 \%$ and $94.1 \%$ vs. $3.9 \%, 92.2 \%$ and $6.9 \%$ respectively).

Table (6) displays the results of women screening behavior about cancer cervix after receiving the health guidelines program. It was evident from figure 5 that almost one fourth $(23.5 \%)$ of the sample sought medical advice and ask for screening to protect themselves. On the other hand, $76.5 \%$ reported that they were confronted with health seeking barriers. These include; fear of being labeled with cancer cervix (39.7\%), fear of shame and stigma $(10.2 \%)$, being unable to disclose their feeling to husband and family (12.8\%), fear of divorce (11.5\%) and logistic reasons (25.6\%) as insufficient time and income. 
Table (1): Distribution of the Studied Women According to their Socio-demographic Characteristics $(n=102)$

\begin{tabular}{|c|c|c|}
\hline \multirow{2}{*}{ Socio-demographic characteristics } & \multicolumn{2}{|c|}{ Studied women $(\mathrm{n}=102)$} \\
\hline & No. & $\%$ \\
\hline Age (years) & & \\
\hline $20-$ & 10 & 9.8 \\
\hline $30-$ & 12 & 11.8 \\
\hline $40-$ & 45 & 44.2 \\
\hline 50 & 45 & 44.2 \\
\hline Min-Max & \multicolumn{2}{|c|}{$20.0-50.0$} \\
\hline Mean \pm SD & \multicolumn{2}{|c|}{$40.5 \pm 9.3$} \\
\hline Educational level & & \\
\hline Illiterate & 14 & 13.7 \\
\hline Read and write / Primary education & 12 & 11.8 \\
\hline Preparatory education / Secondary education & 36 & 35.3 \\
\hline University education or higher & 40 & 39.2 \\
\hline \multicolumn{3}{|l|}{ Current job } \\
\hline Work & 47 & 46.1 \\
\hline Not work & 55 & 53.9 \\
\hline \multicolumn{3}{|l|}{ Marital status } \\
\hline Married & 71 & 69.6 \\
\hline Widow & 28 & 27.5 \\
\hline Divorced & 3 & 2.9 \\
\hline \multicolumn{3}{|l|}{ Monthly income } \\
\hline Enough & 61 & 59.8 \\
\hline Not enough & 41 & 40.2 \\
\hline \multicolumn{3}{|l|}{ Residence } \\
\hline Rural & 14 & 13.7 \\
\hline Urban & 88 & 86.3 \\
\hline \multicolumn{3}{|l|}{ Crowding index } \\
\hline Less than 1 & 12 & 11.8 \\
\hline $1-$ & 69 & 67.6 \\
\hline $2-$ & 17 & 16.7 \\
\hline 3 or more & 4 & 3.9 \\
\hline Min-Max & \multicolumn{2}{|c|}{$0.5-4.0$} \\
\hline Mean \pm SD & \multicolumn{2}{|c|}{$1.5 \pm 0.6$} \\
\hline
\end{tabular}


Table (2): Distribution of the Studied Women According to Their Obstetrical History $(\mathrm{n}=102)$

\begin{tabular}{|c|c|c|}
\hline \multirow[t]{2}{*}{ Obstetric history } & \multicolumn{2}{|c|}{$\begin{array}{c}\text { Studied women } \\
\quad(n=102)\end{array}$} \\
\hline & No. & $\%$ \\
\hline \multicolumn{3}{|l|}{ Number of pregnancy } \\
\hline None & 2 & 2.0 \\
\hline $1-2$ & 20 & 19.6 \\
\hline $3-4$ & 47 & 46.10 \\
\hline $5-6$ & 22 & 21.6 \\
\hline 7 or more & 11 & 10.8 \\
\hline Min-Max & \multicolumn{2}{|c|}{$0-12$} \\
\hline Mean \pm SD & \multicolumn{2}{|c|}{$4 \pm 2.3$} \\
\hline \multicolumn{3}{|l|}{ Number of deliveries } \\
\hline None & 3 & 2.9 \\
\hline $1-2$ & 26 & 25.5 \\
\hline $3-4$ & 54 & 52.9 \\
\hline $5-6$ & 15 & 14.8 \\
\hline 7 or more & 4 & 3.9 \\
\hline Min-Max & \multirow{2}{*}{\multicolumn{2}{|c|}{$\begin{array}{c}0-12 \\
3 \pm 1.9\end{array}$}} \\
\hline Mean \pm SD & & \\
\hline \multicolumn{3}{|l|}{ Number of abortions } \\
\hline None & 75 & 73.5 \\
\hline $1-2$ & 19 & 18.6 \\
\hline $3-4$ & 6 & 5.9 \\
\hline 5 or more & 2 & 2.0 \\
\hline Min-Max & \multirow{2}{*}{\multicolumn{2}{|c|}{$\begin{array}{c}0-7 \\
1 \pm 1.2\end{array}$}} \\
\hline Mean \pm SD & & \\
\hline \multicolumn{3}{|l|}{ Sought medical advice at abortion $[\mathrm{n}=27]$} \\
\hline Yes & 18 & 66.7 \\
\hline No & 9 & 33.3 \\
\hline
\end{tabular}

\#Categories are not mutually exclusive

Table (3): Distribution of the Studied Women According to Their Family and Gynecological History

\begin{tabular}{|l|c|c|}
\hline Family and medical history & No. & \% \\
\hline Family history of cancer cervix & 27 & 26.5 \\
Yes & 75 & 73.5 \\
No & 52 & 51.0 \\
\hline Suffer from vaginal discharge & 50 & 49.0 \\
Yes & & \\
No & 34 & 65.4 \\
\hline Itching with vaginal discharge [n=52] & 18 & 34.6 \\
Yes & & \\
No & 12 & 11.8 \\
\hline Suffer from sexual transmitted infection & 90 & 88.2 \\
Yes & & \\
No & 7 & 6.9 \\
\hline Suffer from HPV & 95 & 93.1 \\
Yes & & \\
No &
\end{tabular}


Figure (1): Distribution of the studied women according to their source of information about cervical cancer.

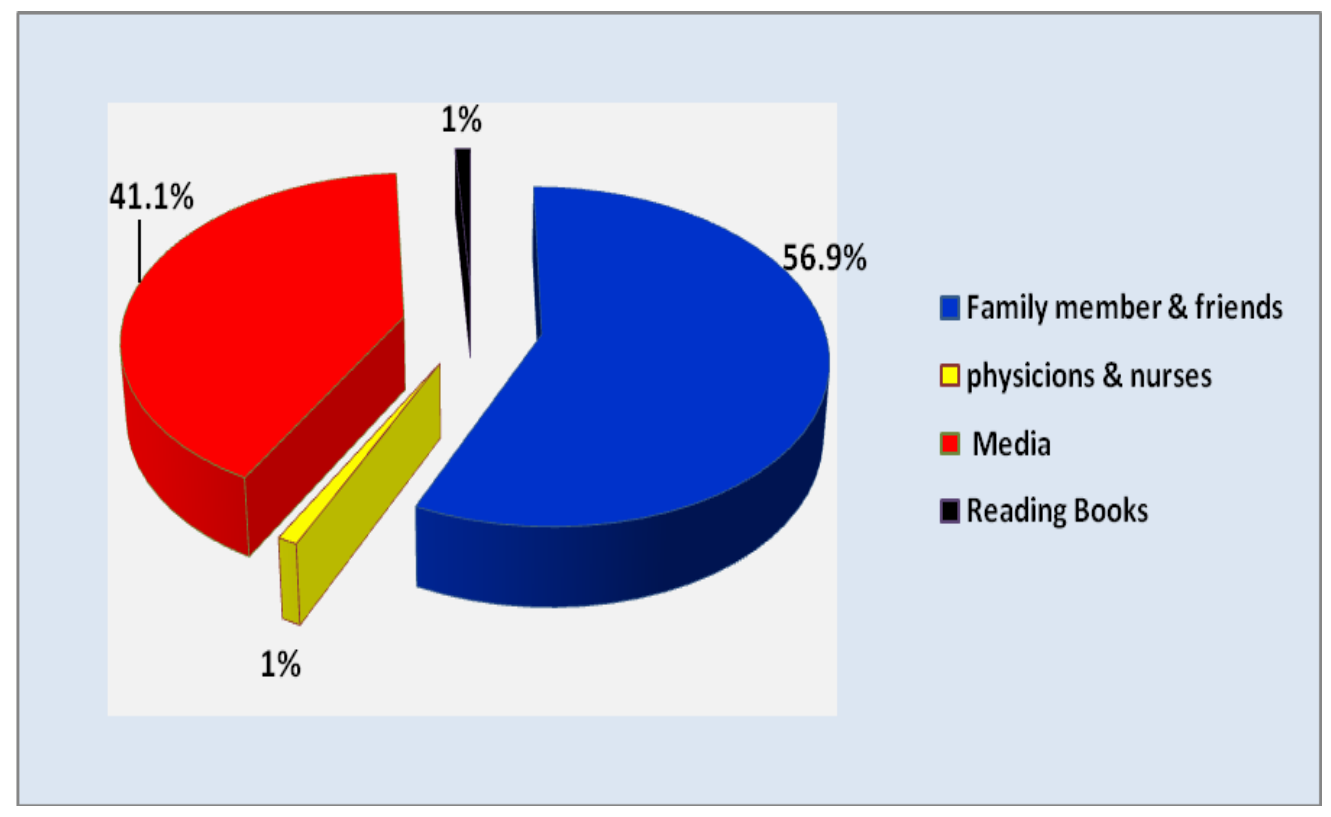

Table (4): Women's Knowledge about Cancer Cervix throughout Pre and Post Test Health Guidelines $\mathrm{N}=(102)$

\begin{tabular}{|c|c|c|c|c|c|c|}
\hline \multicolumn{2}{|c|}{ Knowledge about cancer cervix } & \multicolumn{2}{|c|}{$\begin{array}{c}\text { Pre - test } \\
n=102\end{array}$} & \multicolumn{2}{|c|}{$\begin{array}{l}\text { Post - test } \\
n=102\end{array}$} & \multirow{3}{*}{$\begin{array}{l}\text { Significance } \\
{ }^{\mathrm{MN}} \mathrm{X}^{2}=59.466 \\
\mathrm{P}<0.0001^{*}\end{array}$} \\
\hline & & No. & $\%$ & No. & $\%$ & \\
\hline Know cervix cancer & $\begin{array}{l}\text { Incorrect } \\
\text { Correct }\end{array}$ & $\begin{array}{l}50 \\
52\end{array}$ & $\begin{array}{l}49.0 \\
51.0\end{array}$ & $\begin{array}{l}2 \\
100\end{array}$ & $\begin{array}{l}2.0 \\
98.0\end{array}$ & \\
\hline Site of onset of cervix cancer & $\begin{array}{l}\text { Incorrect } \\
\text { Incomplete } \\
\text { Correct }\end{array}$ & $\begin{array}{l}64 \\
22 \\
16\end{array}$ & $\begin{array}{l}62.7 \\
21.6 \\
15.7\end{array}$ & $\begin{array}{l}2 \\
2 \\
98\end{array}$ & $\begin{array}{l}2.0 \\
2.0 \\
96.1\end{array}$ & $\begin{array}{l}{ }^{\text {мH }} \mathrm{X}^{2}=133.892 \\
\mathrm{P}<0.0001 *\end{array}$ \\
\hline Presence of early curable stages & $\begin{array}{l}\text { Incorrect } \\
\text { Correct }\end{array}$ & $\begin{array}{l}52 \\
50\end{array}$ & $\begin{array}{l}51.0 \\
49.0\end{array}$ & $\begin{array}{l}3 \\
99\end{array}$ & $\begin{array}{l}2.9 \\
97.1 \\
\end{array}$ & $\begin{array}{l}{ }^{\mathrm{MN}} \mathrm{X}^{2}=59.769 \\
\mathrm{P}<0.0001^{*}\end{array}$ \\
\hline Risk factors of cervix cancer & $\begin{array}{l}\text { Incorrect } \\
\text { Incomplete } \\
\text { Correct }\end{array}$ & $\begin{array}{l}81 \\
20 \\
1 \\
\end{array}$ & $\begin{array}{l}79.4 \\
19.6 \\
1.0 \\
\end{array}$ & $\begin{array}{l}1 \\
21 \\
80 \\
\end{array}$ & $\begin{array}{l}1.0 \\
20.6 \\
78.4 \\
\end{array}$ & $\begin{array}{l}{ }^{\mathrm{MH}} \mathrm{X}^{2}=155.123 \\
\mathrm{P}<0.0001 *\end{array}$ \\
\hline $\begin{array}{l}\text { Symptoms and signs of cervix } \\
\text { cancer }\end{array}$ & $\begin{array}{l}\text { Incorrect } \\
\text { Incomplete } \\
\text { Correct }\end{array}$ & $\begin{array}{l}68 \\
34 \\
0\end{array}$ & $\begin{array}{l}66.7 \\
33.3 \\
0.0\end{array}$ & $\begin{array}{l}0 \\
20 \\
82\end{array}$ & $\begin{array}{l}0.0 \\
19.6 \\
80.4\end{array}$ & $\begin{array}{l}{ }^{\mathrm{MH}} \mathrm{X}^{2}=153.63 \\
\mathrm{P}<0.0001 *\end{array}$ \\
\hline
\end{tabular}


Table (5): Women's Knowledge about Cancer Cervix throughout Pre and Post Test Health Guidelines (Cont.)

\begin{tabular}{|c|c|c|c|c|c|c|}
\hline \multirow{2}{*}{\multicolumn{2}{|c|}{ Knowledge about cancer cervix }} & \multicolumn{2}{|c|}{$\begin{array}{c}\text { Pre - test } \\
n=102\end{array}$} & \multicolumn{2}{|c|}{$\begin{array}{c}\text { Post - test } \\
n=102\end{array}$} & \multirow[t]{2}{*}{ Significance } \\
\hline & & No. & $\%$ & No. & $\%$ & \\
\hline $\begin{array}{l}\text { Predisposing factors of cancer } \\
\text { cervix }\end{array}$ & $\begin{array}{l}\text { Incorrect } \\
\text { Incomplete } \\
\text { Correct }\end{array}$ & $\begin{array}{l}98 \\
0 \\
4\end{array}$ & $\begin{array}{l}96.1 \\
0.0 \\
3.9\end{array}$ & $\begin{array}{l}31 \\
64 \\
7\end{array}$ & $\begin{array}{l}30.4 \\
62.7 \\
6.9\end{array}$ & $\begin{array}{l}{ }^{\mathrm{MH}} \mathrm{X}^{2}=99.61 \\
7 \\
\mathrm{P}<0.0001 *\end{array}$ \\
\hline $\begin{array}{l}\text { Measures used for prevention of } \\
\text { cancer cervix }\end{array}$ & $\begin{array}{l}\text { Incorrect } \\
\text { Correct }\end{array}$ & $\begin{array}{l}8 \\
94\end{array}$ & $\begin{array}{l}7.8 \\
92.2\end{array}$ & $\begin{array}{l}0 \\
102\end{array}$ & $\begin{array}{l}0.0 \\
100.0\end{array}$ & $\begin{array}{l}{ }^{\mathrm{MN}} \mathrm{X}^{2}=8.327 \\
\mathrm{P}=0.007 *\end{array}$ \\
\hline $\begin{array}{l}\text { Duration between successive pap } \\
\text { smears }\end{array}$ & $\begin{array}{l}\text { Incorrect } \\
\text { Incomplete } \\
\text { Correct }\end{array}$ & $\begin{array}{l}95 \\
0 \\
7\end{array}$ & $\begin{array}{l}93.1 \\
0.0 \\
6.9\end{array}$ & $\begin{array}{l}0 \\
6 \\
96\end{array}$ & $\begin{array}{l}0.0 \\
5.9 \\
94.1\end{array}$ & $\begin{array}{l}{ }^{\mathrm{MH}} \mathrm{X}^{2}=177.9 \\
03 \\
\mathrm{P}<0.0001 *\end{array}$ \\
\hline $\begin{array}{l}\text { Total Score of knowledge about c } \\
\text { Poor (less than } 60 \%) \\
\text { Good ( } 60 \% \text { or more) }\end{array}$ & r cervix & $\begin{array}{c}100 \\
2\end{array}$ & $\begin{array}{r}98.0 \\
2.0\end{array}$ & $\begin{array}{c}2 \\
100\end{array}$ & $\begin{array}{l}2.0 \\
98.0\end{array}$ & $\begin{array}{c}\mathrm{t}=35.758 \\
\mathbf{P}<0.0001 *\end{array}$ \\
\hline $\begin{array}{l}\text { Min-Max } \\
\text { Mean } \pm \text { SD }\end{array}$ & & & $\begin{array}{l}71.1 \\
\pm 14.3\end{array}$ & & $\begin{array}{l}97.4 \\
\pm 9.5\end{array}$ & \\
\hline
\end{tabular}

Table (6): The Screening Behavior and Health seeking barriers to conduct screening about Cancer Cervix among the Studied Sample after Receiving the Health Guidelines $(\mathrm{N}=102)$

\begin{tabular}{|l|c|c|}
\hline \multirow{2}{*}{ Incidence of Screening Behavior } & \multicolumn{2}{|c|}{$\begin{array}{l}\text { Studied women } \\
(\mathbf{n = 1 0 2})\end{array}$} \\
\cline { 2 - 3 } & No. & $\mathbf{\%}$ \\
\hline Conduct Screening for cancer cervix: & 78 & 76.5 \\
Yes & 24 & 23.5 \\
No & & \\
\hline Health seeking barriers about conduct screening: $[\mathbf{n = 7 8 ]}$ & 31 & 39.7 \\
Fear of being labeled with cancer cervix & 8 & 10.2 \\
Fear of shame and stigma & 10 & 12.8 \\
Unable to disclose their feeling to husband and family & 9 & 11.5 \\
Fear of divorce & 20 & 25.6 \\
Insufficient time and income & \\
\hline
\end{tabular}

\section{DISCUSSION:}

Cervical cancer, though largely preventable, is the second most common female cancer internationally and a leading cause of cancer deaths among females in the developing countries (Ashford et al., 2005; Waggoner 2003). In 2010, the global 
incidence of cervical cancer was 454,000 cases, of which about $50 \%$ resulted in death (Forouzanfar et al., 2011).

More than $85.0 \%$ of global cervical cancer deaths occur in low and middle-income countries, reflecting poor control and early detection measures in these countries. In 2008, over 1.1 million people died of cancers in the South East Asia Region. Of these, 35\% deaths were due to breast and cervical cancers (WHO, 2010).

Egypt has a population of 25.76 million women aged 15 years and older who are at risk of developing cervical cancer. The current estimates indicate that every year about 514 women are diagnosed with cervical cancer and 299 die from the disease. This condition affects not only the health and lives of the women, but also their children, families and their communities at large (WHO/ICO, 2010).

Early detection can greatly increase the chance of successful treatment resulting in approximately $40 \%$ reduction in incidence and mortality associated with invasive cancer (Dang et al., 2014). The detection of most of cervical cancer cases at a late stage is an indication that the freely provided screening services are not utilized or are poorly utilized.

Counseling by a nurse midwife is considered very important in order to achieve the purpose of increasing awareness of risk factors and encourage screening behavior to help the woman to have the right information and to correct their misconceptions.

There are no published data on cervical cancer knowledge and screening behavior in El-Suez City. Therefore, this study attempts to describe level of knowledge, current screening behaviors and health seeking barriers to screening among studied women.

Finding of the present study has shown that the increase of low socio-economic level and increase in number of deliveries are predicting factors for cervical cancer. This corresponds well with the finding of Daley, (2007) who reported that low socioeconomic status is recognized as a risk factor for many health problems, including cervical cancer, particularly in low-resource settings. Women with low SES often have limited income, restricted access to health care services, poor nutrition, and a low level of awareness about health issues and preventive behavior. All of these factors can make them more vulnerable to illness and preventable diseases such as cervical cancer.

Pooled data from eight case-control studies on invasive cervical cancer and two studies on carcinoma in situ (CIS) from four continents suggest that, compared to women who had never given birth, those with three or four full-term pregnancies had 2.6 times the risk of developing cervical cancer; women with seven or more births had 3.8 times the risk (Ferlay et al., 2012).

Other studies corroborate this positive relationship found between high parity and cervical cancer (Franceschi \& Bosetti, 2003). The physiologic reason for the 
association is unclear; possibilities include hormonal factors related to pregnancy or cervical trauma associated with delivery.

The current study finding reveals the prolonged use of IUD and contraceptive pills, which was mostly done with no follow up of medical advice. In this regard research suggests that there is a potential long-term relationship between prolonged use of oral contraceptives and development of cervical cancer. An analysis of pooled data from ten case-control studies of patients with invasive cervical cancer or CIS suggests that long-term use of oral contraceptives could increase the risk of cervical cancer by up to four-fold in women with HPV infection, (American Cancer Society, 2015). Pending the results of several studies currently under way, WHO convened a meeting of experts that focused on cervical cancer, oral contraceptives, and parity. The group published recommendations against changing oral contraceptive prescribing practice or use (Ministry of Health-Bhutan, 2009).

Furthermore, women who are co-infected with HPV and another sexually transmitted agent, such as Chlamydia trachomatis or herpes simplex virus-2 (HSV-2), are more likely to develop cervical cancer than are women who are not co-infected. This is matching with the present result which found that almost half of the studied sample was exposed to vaginal infection and dyspareunia.

In this respect one pooled analysis of seven case-control studies examining the effect of HSV-2 infection in the etiology of invasive cervical cancer found that among HPV DNA-positive women, HSV-2 was associated with about a three-fold increased risk of developing cervical cancer after adjustment for potential confounders (Saha et al., 2010).

The current study finding revealed there is poor cervical cancer knowledge of risk factors and detection method among the studied sample at the pretest. Similar studies conducted by Tan, (2010) in Malaysia, Muhammad Eshanul, (2010) in South Africa and (Saha et al., 2010) in Kolkata and Daley, (2007) and Ingledue, (2004) in United States of America. This suggests that the current methods used for measuring women awareness for cervical cancer health guidelines were valid for this population.

Less than one fourth of the participants were aware of the purpose, technique and timing of Pap test at the pre-test which is much lower than those reported from studies conducted among Taiwanese women (80\%) and Greek students (94\%) (Hsu et al., 2011; Bakogianni , et al., 2012). This was significantly improved at the posttest which indicates that the majority of the participants acquired the essential knowledge about the Pap smear test.

Very few number of the present study respondents knew about the link between risk factors and cervical cancer at the pre-test which is slightly higher than studies reported from Sri Lanka (20.8\%), Nepal (0.2\%) and Ghana (1\%) but much lower than that reported from studies conducted in Malaysia (61\%) (Joy, 2011; Shoka, 2009; 
Redhwan, 2010). This may be due to the absence of a standardized system of disseminating cervical cancer education to women other than health providers.

Knowledge of the link between cervical cancer and the possibility of prevention of cancer and treating the HPV which is the active agent in the occurrence of this disease in the present study was found to be higher especially after the post-test than that reported from previous mentioned studies conducted among female youths in Sri Lanka (27.7\%), India (26.1\%) and Nepal (38.8\%). This indicates a significant difference in knowledge related to the above mentioned point between pre-guidelines and after guidelines surmised that educational efforts were appropriate for the target audience.

The present study found that almost one fourth of the respondents reported doing screening test after the program despite it being freely available in the hospital. Studies conducted elsewhere yielded similar results of low Pap smear test uptake. For example, studies among female students in Nigeria (Gerend and Magloire, 2008), Malaysia (Chan, 2009) and Turkey Gerend, (2009) showed low utilization of Pap smear test.

In general, while the poor uptake of screening test including the Pap test could be explained by the fact that people do not usually undergo health checks without first experiencing health problems, the absence of systematic and active promotion of screening program in the country may be attributable to the low utilization of Pap smear test in El-Suez city. Only those who visit gynecological clinics are sometimes recommended to undergo Pap smear test.

When women asked about their health screening barriers concerning cancer cervix, the majority of the study respondents cited thought that they wouldn't needed it, embarrassment of being examined by male health professional and fear of finding out cancer. These were the commonest reasons for not doing such screening. This suggest the necessity of expanding the role of the nurse midwife to assist with the screening tests and help women to overcome these misconception and cope with their problem as early as they could.

Similarly a study conducted among female university students in Japan (Ghotbi and Anai, 2012) revealed "embarrassment of being examined by male health professional" as an important barrier to Pap smear Test. Studies conducted elsewhere Moreira, (2006) and Yamkarem, (2010) found "embarrassment" as a common barrier to Pap test. Study conducted among 10th graders in the United States of America Villar and Rabello, (2011) found fear of cancer (37\%) as a barrier to Pap smear test.

Therefore, in order to overcome the common barriers mentioned, it may therefore be beneficial to emphasize on the availability of trained midwife to conduct the Pap smear test and to increase awareness about the recommended age-group for Pap 
smear test in all cervical cancer related public awareness/education activities in gynecological setting and in the various media.

It is important to note that despite the fact that the present study respondents knowing that early detection can prevent development of cervical cancer; the poor screening behavior suggests that factors other than education may play a major role in influencing screening practices. It may be useful to recommend study exploring socio-cultural and economic factors associated with screening behavior of women and measures to cope with these factors.

\section{CONCLUSION:}

\section{Based on study findings, it can be concluded that:}

The health guidelines were effective improving women's knowledge and behavior related to cervical cancer. There is a significant improvement post intervention in all items of knowledge regarding cervical cancer. There is also a significant improvement post intervention in all items regarding behavior except the barriers toward Pap smear screening which faced them.

\section{RECOMMENDATIONS:}

The necessity of expanding the role of the nurse midwife to assist with the screening tests and help women to overcome these misconceptions and cope with their problem as early as they could, Educate women about screening to reduce the negative attitude of embarrassment attached to the procedure, Information on the availability of cervical cancer treatment should be available to the public to reduce anxiety associated with the outcome of cervical cancer screening and Finally, the recommendation of a larger scale study in the nation and the study to be conducted out in the community to also target women without health seeking behaviors.

\section{REFERENCES:}

Abd El-Azim S., Lotfy M. and Omr A. (2011): Detection of human papillomavirus genotypes in cervical intraepithelial neoplasia and invasive cancer patients: Sharkia Governorate, Egypt. Clin Lab; 57(6):363-371.

American Cancer Society (2013): What are the key statistics about cervical cancer? Availablefrom:http://www.cancer.org/Cancer/CervicalCancer/DetailedGuide/cervical cancerkey- statistics/2013 [Last accessed on 2013 Nov 4].

Ashford L. and Collymore Y. (2005): Preventing Cervical Cancer Worldwide. Population Reference Bureau, Policy brief. Available At http://www.prb.org/pdf05/ preventcervcancer-brief_eng.pdf.

American Cancer Society Guidelines for the Early Detection of Cancer (2015): Available at http://www.cancer.org. 
Bakogianni GD., Goutsou SC., Liti MV., Rizopoulou SI., Nikolakopoulos KM. and Nikolakopoulou NM. (2012): Knowledge, attitude, and practice of cervical cancer screening among Greek students: a short report. Int J Adolescent Med Health, 24(4):329-330.

Consul S., Agrawal A., Sharma H., Bansal A., Gutch M. and Jain N. (2012): Comparative study of effectiveness of Pap smear versus visual inspection with acetic acid and visual inspection with Lugol's iodine for mass screening of premalignant and malignant lesion of cervix. Indian J Med Paediatr Oncol; 33:161-165.

Chan SS., Ng BH. and Lo WK. (2009): Adolescent Girls' Attitude on Human Papillomavirus Vaccination. J Pediatric Adolescent Gynecol.;22:85-90.

Daley CM. (2007): Students' Knowledge of risk and screening recommendations for breast, cervical, and testicular cancers. J Cancer Education, 22:86-90.

Dang J., Lee J. and Tran JH. (2014): Knowledge, attitudes, and beliefs regarding breast and cervical cancer screening among Cambodian, Laotian, Thai, and Tongan Women. J Cancer Education, 25:595-601.

Farshbaf-Khalili A., Salehi-Pourmehr H., Shahnazi M., Yaghoubi S. and Gahremani-Nasab P. (2015): Cervical cancer screening in women referred to healthcare centres in Tabriz, Iran. Niger Med J; 56:28-34.

Ferlay J., Soerjomataram I., Ervik M., Dikshit R., Eser S., Mathers C., Rebelo M., Parkin DM., Forman D. and Bray F. (2012): Cancer Incidence and Mortality Worldwide: IARC Cancer Base No. 11. Available at http://globocan.iarc.fr/Pages/

Ferlay J., Shin HR., Bray F., Forman D., Mathers C. and Parkin DM. (2010): Estimates of worldwide burden of cancer in 2008: GLOBOCAN 2008. Int J Cancer; 127(12):2893-917.

Forouzanfar MH., Foreman KJ., Delossantos AM., Lozano R., Lopez AD., Murray CJ. and Naghavi M. (2011): Breast and cervical cancer in 187 countries between 1980 and 2010: A systematic analysis. Lancet, 378(9801):1461-1484.

Franceschi S. and Bosetti C. (2003): Role of parity and human papillomavirus in cervical cancer: the IARC multicentre case-control study. Lancet 359(9312)10931101.

Gerend MA. and Magloire ZF. (2008): Awareness, knowledge, and beliefs about human papillomavirus in a racially diverse sample of young adults. J Adolescent Health; 42(3):237-242. 
Ghotbi N. and Anai A. (2012): Assessment of the knowledge and attitude of female students towards cervical cancer prevention at an international university in Japan. Asian Pac J Canc Prev 2012, 13(3):897-900.

Hsu YY. Cheng YM. Hsu KF. Fetzer SJ. And Chou CY. (2011): Knowledge and beliefs about cervical cancer and human papillomavirus among Taiwanese undergraduate women. Oncology Nurses Forum, 38(4):E297-E304.

Jhingran A, Russel AH, Seiden MV, et al (2014): Cancers of the cervix, vagina and vulva. In: Neiderhuber JE, Armitage JO, Doroshow JH, Kastan MB, Tepper JE eds. Abeloff's Clinical Oncology. 5th ed. Philadelphia, Pa; Elsevier: 1534-1574.

Joy T., Sathian B., Bhattarai C. and Chacko J. (2011): Awareness of Cervix cancer risk factors in educated youth: A cross-sectional, questionnaire based survey in India, Nepal and Sri Lanka. Asia Pacific J Cancer Prevention, 12:1707-1712.

Muhammad Eshanul H. (2010): Cervical cancer awareness and prevention behavior among female university students in South Africa. Asian Pacific J Cancer Prevention, 11:127-130.

Ministry of Health: Cervical Cancer Screening Guideline (2009): Ministry of Health, Royal Government of Bhutan.

Moreira ED., de Olivereira GG. and Neves RC. (2006): Assessment of Knowledge and Attitude of Young Uninsured Women toward Human Papillomavirus Vaccination and Clinical Trials. J Pediatric Adolescent Gynecol; 19:81-87.

National Cancer Registry (2002): The National Cancer Registry News letter, Ministry of Health and Population, Egypt.

Redhwan Ahmed AN., Low WY. and Zaleha MdI. (2010): Knowledge and barriers towards cervical cancer screening among young women in Malaysia. Asian Pacific J Canc Prevention, 11:867-873.

Rahatgaonkar $\boldsymbol{V}$. (2012): VIA in cervical cancer screening, IOSR Journal of Dental and Medical Sciences (IOSRJDMS); 1(1): 01-04.

Saha A., Nag Chaudhury A., Bhownik P. and Chatterjee R. (2010): Awareness of cervical cancer among female students of premier college of Kolkata, India. Asian Pacific J Cancer Prevention, 11:1085-1090.

Shokar NK. (2009): Cervical cancer screening among college students in Ghana: knowledge and health beliefs. Int J Gynecologic Cancer, 19(3): 412-416.

Tan YY., Hesham R. and Qodriyah HMS. (2010): Knowledge and attitude of university students in health sciences on the prevention of cervical cancer. Med $\mathbf{J}$ Malaysia, 65:1. 
Villar LM., Rabello AD. and Salatede PaulaV. (2011): Evaluative knowledge about toward HumanPapillomavirus infectionamong Barasilian health professions. Asian Pacific J Cancer Prev; 3251- 3256.

Waggoner SE. (2003): Cervical cancer. Lancet, 361(9376):2217-2225.

World Health Organization (WHO) (2010): Human papillomavirus and cervical Cancer. 2010. Available at http://www.who.int/ mediacentre/factsheets/fs380/en/

WHO/ICO Information Centre on HPV and Cervical Cancer (HPV Information Centre) (2010): Human Papillomavirus and Related Cancers in Egypt. Summary Report. 2010. Available at www.who.int/hpvcentre.

Yamkarem E., Rijan G., Kawlak T. and Karadiniz G. (2010): Assessing the role of education on Turkish University students, Knowledge about HPV and related diseases. Asian Pacific J Cancer Prev; 1703-171. 


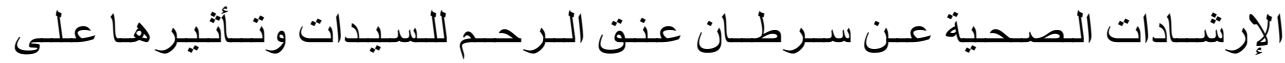

$$
\begin{aligned}
& \text { ســـوكهن للفحص في مدينـة الـسـويس }
\end{aligned}
$$

أ.م. د/ انتصار فتوح عبد المنعم ـ د/ منى محمد يونس - د/ السيدة حمدي نصر - عزة شعبان محمد أستاذ مساعد تمريض صحة الأم وحديثي الولادة ـ كلية التمريض - جامعة حلوان، مدرس تمريض صدئ

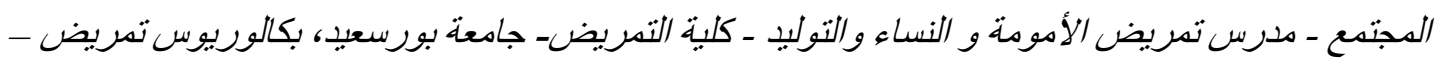
جامعة قناة السوبيس

\section{الـــلاصــة}

الدراسة الحالية دراسة شبة تجريبية هدفها تقييم معلومات السيدات عن سرطان عنق الرحم وتأثير الإرشادات الصحية على سلوكهن للفحص عن سرطان عنق الرحم. وشملت عينة البحث (r 1) سيدة من السيدات المترددات على عيادة الأورام في التأمين الصحي بالسويس، وقد تم تجميع البيانات عن طريق استخدام استمارة استبيان للسيدات لتقييم معلومات السيدات عن سرطان عنق الرحم وتأثير الإرشادات الصحية على سلوكهن للفحص عن سرطان عنق الرحم وتم تجميع الاستمار ات قبل البدء في الإرشادات وبعد شهر من تتفيذها مباثرة. وقد أسفرت نتائج البحث على أن السيدات ليس لديهم معلومات عن سرطان عنق الرحم فقد كانت غير مرضيه (r\%) ولكن بعد اعطائهن الإرشادات الصحية اكتسبوا معلومات واصبحت نسبة معلوماتهن مرضيه بنسبة (9^\%). أما بالنسبة لسلوك السيدات فقد تغير سلوكهن تجاه الفحص وقامت بعمل الفحص (0,0\%\%) من السيدات ،وباقي السيدات كان يوجد لديهن حواجز وعو امل لعمل الفحوصات الخاصة بسرطان عنق الرحم ـ بناء على نتائج الدراسة أوصى بزيادة التثقيف الصحي الفعال في تحسين معلومات وسلوك السيدات تجاه عمل فحوصات سرطان عنق الرحم ، بالنسبة للسيدات المترددات علي عيادات أمر اض النسا وتعانين من عدوي الأمر اض التناسلية المتكررة والأمر اض المناعية. يجب الاهتمام بعمل الفحوصات لأنهم الأكثر عرضه لسرطان عنق الرحم ، وينبغي عمل وتنفيذ برنامج تعليمي متكامل واعطاء التطعيمات للوقاية من خطر الإصابة بسرطان عنق الرحم بين السيدات الأكثر عرضه.

الكلمات المرشدة : سرطان عنق الرحم، الدعلومات، السلوك، طرق الفحص، عوائق الفحص. 